\title{
JGA BANDUNG \\ Pengetahuan Orang Sunda dalam Ramalan dan Antisipasi terhadap Perubahan Fenomena Alam
}

\author{
Oleh Nandang Rusnandar \\ Balai Pelestarian Sejarah dan Nilai Tradisional Bandung \\ Jl. Cinambo No. 136 Ujungberung - Bandung 40294
}

Naskah diterima: 6 Juni 2011

Naskah disetujui: 6 Agustus 2011

\begin{abstract}
Abstrak
Penelitian mengenai Uga Bandung Pengetahuan Orang Sunda dalam "Ramalan" dan "Antisipasi" terhadap Perubahan Fenomena Alam, bertujuan untuk mendeskripsikan Uga Bandung yang beredar di masyarakat Bandung. Metode yang dipergunakan adalah metode penelitian deskriptif dengan pendekatan kualitatif. Data diperoleh melalui wawancara mendalam dan penggunaan dokumen. Uga Bandung mendeskripsikan perjalanan dan perkembangan sebuah kota yaitu Kota Bandung sebagai pusat orientasinya yang pada akhirnya menjadi Bandung heurin ku tangtung. Uga Bandung pun di dalamnya mengungkapkan nilai-nilai dalam bentuk simbol sebagai antisipasi terhadap fenomena perubahan alam, sehingga perubahan itu dapat dikendalikan sesuai dengan situasinya.
\end{abstract}

Kata kunci: Uga Bandung, ramalan, antisipasi.

\begin{abstract}
Uga Bandung describes the progress and development of the city of Bandung from the very beginning until today's populous city. Uga Bandung contains certain values in the form of symbols for anticipating the change in nature. The main goal of this research is to describe Uga Bandung that are vastly known among the people of Bandung. The author conducted descriptive analytical method and qualitative approach. Data were obtained through in-depth interview and secondary sources.
\end{abstract}

Keywords: Uga Bandung, forecast, anticipation 


\section{A. PENDAhULUAN}

Kebudayaan suatu bangsa dapat menggambarkan identitas bangsa, di dalamnya terkandung nilai-nilai budaya dalam seluruh aspek kehidupan manusia atau bangsanya, di samping mengandung pandangan hidupnya. Kebudayaan itu merupakan bentukan dari kristalisasi nilai-nilai kehidupan dari masanya yang diwariskan nenek moyang untuk memberikan gambaran terhadap generasi penerusnya. Kaitannya dengan nilai budaya suatu bangsa, khususnya eksistensi kebudayaan Sunda pada masa kini, sangat ditentukan oleh bentuk kehidupan yang tidak lepas dari aspek sosial ekonomi, politik, psikologi, kebudayaan, dan sejarah yang mengelilingi situasi dan kondisi bangsa itu sendiri.

Dalam menghadapi era globalisasi dan era reformasi yang terus menggelinding dan menggilas setiap individu dan masyarakat tanpa melihat; apa dan siapa, kapan dan di mana. Maka kebudayaan Sunda sebagai salah satu bagian dari kebudayaan mondial tersebut, sudah tertanam sistem dan tatanan untuk kehidupan yang akan dijemputnya. Di dalamnya terdapat solusi untuk menghadapi masalah ini, dengan demikian solusi tersebut dapat memberikan gambaran yang konfrehensif untuk dapat memposisikan urang Sunda agar dapat ikut berpartisipasi dalam 'mozaik kebudayaan mondial'. Uga merupakan salah satu bentuk upaya beradaptasi terhadap keadaan alam sekelilingnya, baik untuk memprediksi perkembangan maupun mengantisipasi dampak dari perkembangan itu sendiri. Uga terciptakan berdasarkan kehidupan dan tumbuh dengan sendirinya dengan tujuan untuk memenuhi kebutuhan manusia. Kalimat yang tertuang dalam $u g a$, selalu mengungkapkan simbolsimbol dalam kehidupan, sehingga maknanya dapat diartikan dan dibaca melalui ujaran dan anjuran.

Ernst Cassirrer (1987: 41-48) menjelaskan bahwa "/.../ manusia adalah animal symbolicum, bahwa pemikiran simbolis dan tingkah laku simbolis merupakan ciri yang betulbetul khas manusiawi". Simbol berbeda dengan tanda, yang memiliki dua bidang pembahasan yang berlainan. Tanda adalah bagian dari dunia fisik, sedangkan simbol adalah bagian dari dunia makna manusiawi. Keistimewaan interaksionis simbolis ialah manusia dilihat saling menafsirkan atau membatasi masingmasing tindakan mereka dan bukan hanya saling bereaksi pada setiap tindakan menurut mode stimulus respon. Seseorang tidak langsung memberikan respon pada tindakan orang lain, tetapi didasari oleh pengertian yang diberikan kepada tindakan itu. Makna berasal dari interaksi dengan orang lain terutama dengan orang yang dianggap cukup berarti. "Bagi seseorang, makna dari sesuatu berasal dari cara-cara orang lain bertindak terhadapnya dalam kaitannya dengan sesuatu itu. Tindakan-tindakan yang mereka lakukan akan melahirkan batasan sesuatu bagi orang lain" (Blumer, 1969 dalam Soeprapto, 2002; 152). Makna yang terkandung dalam sebuah simbol bukan terletak pada simbol itu sendiri, manusialah yang memberikan makna. Uga dipahami sebagai ungkapan yang berhubungan dengan berbagai macam peristiwa yang akan dihadapi pada masa yang akan datang dan sangat penting dalam kehidupannya. Uga dapat memiliki kedalaman makna simbolik yang bersifat memperkuat motivasi 
untuk menghadapi masa yang akan datang sebagai sebuah tantangan, karena di dalamnya uga mampu memprediksi sehingga dengan uga pula dapat memberikan kepercayaan dan kepastian bagi pendukungnya.

Situasi dan kondisi kehidupan secaraglobal puntidak luput dariperhatian karuhun Sunda, karena semua merupakan fenomena alam yang sangat disadari oleh karuhun dan menjadi peringatan yang harus diperhatikan oleh anak cucu atau generasi mendatang. "Zaman edan" seperti saat ini telah diperingatkan dan diprediksi pula oleh karuhun agar anak cucu berhati-hati dalam menghadapi dan mengantisipasinya. Wangsit dari Raja Pajajaran yang ada di Kabuyutan Galunggung, menyebutkan bakal terjadi zaman edan dan situasi yang tidak terkendali.

Karuhun Sunda yang dengan kearifannya itu mampu menempatkan diri sesuai dengan zamannya dan bahkan mampu meneropong dan menerobos ke masa yang akan datang. Mereka menempatkan diri sesuai nilai hakiki demi mengisi dan bahkan memperingatkan generasi yang akan datang (kini) agar jangan sampai terpuruk oleh hal-hal yang bersifat profan tadi. Dalam sebuah prasasti Kawali di Kabupaten Ciamis, yang baru ditemukan pada tahun 1995 sebagian kalimat menyatakan bahwa: "/.../ulah baténga bisi kakéréh//" artinya jangan melanggar pamali, dapat menimbulkan kesengsaraan. (Rusnandar 1995, dalam Laporan Penemuan Prasasti Kawali ke VIII). Akibat distorsi yang disebabkan hilangnya mata rantai kesinambungan antara tata nilai, budaya, adat istiadat, bahkan pedoman hidup pamali dan hideng, maka orang Sunda semakin kehilangan arah dan tujuan dari proses kehidupan yang lebih makro dan holistik.

Untuk dapat mengerti pesan yang terkandung di dalam $u g a$, sangat diperlukan pengertian yang jauh lebih dalam untuk menyingkap simbol di dalamnya. Kehidupan masyarakat Sunda, merupakan hasil dari kebudayaan yang dibingkai menurut konsep simbolik yang diwariskan dari genersai ke generasi sebagai pegangan dalam tindakannya untuk mendukung kebudayaan tersebut. Kebudayaan merupakan sistem pemaknaan yang bersifat interpretatif, di dalamnya terdapat jaring makna berupa simbol-simbol tempat bergantungnya manusia dalam kehidupan bermasyarakat. Menurut Geertz (1992: 5), kebudayaan adalah jaringan makna yang dalam hal ini dianalogikan sebagai hewan atau laba-laba yang merajut jaring-jaringnya sendiri. Manusia menggunakan simbol untuk memberi isyarat dalam menyampaikan pandangan tentang makna, dan melalui bentuk simbolik itu manusia berkomunikasi, melestarikan dan mengembangkan pengetahuan mereka tentang hidup dan sikapnya terhadap kehidupan. Untuk pemaknaan simbol tersebut, pengetahuan yang dimiliki masyarakat Sunda yaitu apa yang disebut dengan pancacuriga, yaitu pengetahuan tentang lima "S" (silibsindir, simbul, siloka, dan sasmita) yang melatarbelakangi budaya berpikir orang Sunda. Kearifan dan kesungguhan sebagai manusia terkini dituntut untuk mengejawantahkannya. Kearifan dalam berpikir, bertindak, dan berbicara adalah kunci untuk membuka tabir itu. Pada akhirnya kita mampu nganjang ka isukan 'mengetahui hari esok', ngalongok $k a$ pageto 'menengok hari-hari yang akan 
datang', dan nyaba ka baheula 'melihat hari-hari yang telah lalu'.

Mungkin ada pertanyaan: "Apakah rangkaian kejadian peristiwa sekarang ini lepas dari perhatian karuhun Sunda ?" Ternyata tidak. Apa yang terjadi hari ini adalah pantauannya yang tak lepas dari rangkulan daya ramalannya. Beberapa pernyataan karuhun dalam uga dari berbagai daerah di Jawa Barat yang menunjukkan antisipasi dan menjawab fenomena alam yang terjadi kini.

Berbagai contoh uga (ramalan) atau cacandran yang akan terjadi 'the bible of the folk', dapat dikatakan bahwa uga ini merupakan 'futurisme folklore' yang berbeda dengan futurologi ilmiah yang berdasarkan data statistik, pengamatan dan analisisnya yang menggunakan metodologi ilmiah. Sedangkanugahanyadisusunberdasarkan ilham, wangsit, insting, dan penghayatan 'kontemplasi'. Dengan kearifannya, karuhun mampu mengabstraksikan dan menggeneralisasikan putaran perjalanan hidup manusia sehingga melahirkan uga.

Secara umum di Jawa Barat, dapat dikenal beberapa jenis uga di antaranya :

1. Dalam bentuk kata-kata yang dihubungkan dengan tanda alam, baik secara simbolik atau perlambang atau dilisankan secara harfiah. Contoh uga perlambang adalah Uga Bandung, di dalam uga tersebut dinyatakan bahwa "Bangsa Indonesia bisa adil jeung sejahtera lamun Kawah Ratu geus ngahiji jeung Kawah Upas”. Para pemimpin bangsa (Kawah Ratu) sudah mau menerima aspirasi rakyat (Kawah Upas), baru kemudian Indonesia akan mengalami masa makmur dan adil.
2. Uga mampu memberikan gambaran yang lebih universal, walaupun uga terlahir dari hasil pemikiran lokal namun dapat berlaku secara global. Disebutkan dalam sebuah uga yang tertulis dalam sebuah lembaran kusam (naskah kertas Nederlander) yang berbahasa Sunda bercampur bahasa Melayu ditulis dengan tulisan beraksara Arab Pegon tertera di dalamnya "Yén engké bakal karandapan hujan racun!" Tampak bahwa ramalan hujan racun itu terjadi di Negara-negara Eropa, Jepang, RRC, India, Kanada dan Amerika. Bahkan yang lebih mengenaskan yaitu ketika kejadian Chernobyl di Sovyet Rusia.

3. Uga Sunda dalam wujud pantun (carita pantun), seperti Pantun Bogor.

4. Uga dalam permainan dan nyanyian barudak Sunda.

5. Uga dalam nyanyian orang dewasa yang biasa dinyanyikan dalam sebuah sisindiran dan wawangsalan.

Uga sebagai ramalan atau prediksi, jika dilihat dari rentang waktu penciptaan dan penuturan dari ego penutur hingga pembuktian. Uga itu dapat menggambarkan pertama, sesuatu yang telah lama terjadi; kedua, sesuatu sedang terjadi, dan ketiga, sesuatu yang belum terjadi. Atau apabila dilihat dari orientasi waktu dari prosesnya, maka uga dapat menggambarkan suatu kejadian yang telah terjadi di masa lampau, masa sekarang, dan masa yang akan datang.

Berdasarkan pada identifikasi masalah penelitian, maka tujuan dari penelitian ini adalah untuk menggali kembali Uga Bandung yang ada di masyarakat Sunda, dan melihat peran Uga Bandung tersebut dalam kehidupannya. 
Pengumpulan data mengenai Uga Bandung, mengambil lokasi penelitian di 'Bandung Raya' Provinsi Jawa Barat. Penelitian ini tidak pula melepaskan kampung-kampung adat yang ada di sekitar Kota Bandung. Hal itu disebabkan karena kampung-kampung adat dianggap merupakan daerah yang representatif dalam artian masih memiliki keaslian dalam tradisi, khsusunya tradisi Sunda. Pengertian Bandung Raya penulis pergunakan untuk merujuk pada daerahdaerah yang terletak di pinggiran Kota Bandung yang secara administratif tidak termasuk ke dalam wilayah Kota Bandung, tapi masuk ke dalam wilayah administratif Kabupaten Bandung atau Kota Cimahi.

Analisis data penelitian ini dilaksanakan bersamaan waktunya dengan tahap pengumpulan data di lapangan, bahkan analisis data dilakukan sejak awal dan sepanjang proses penelitian berlangsung. Seperti penelitian kualitatif pada umumnya, analisis data dilakukan pada saat berlangsungnya pengumpulan data. Penelitian ini menggunakan pendekatan kualitatif yang menuntut telaah rinci atas hal-hal yang bersifat spesifik dari objek yang diteliti. Teknik analisis data dilakukan dengan induktif analisis yaitu suatu rancangan pengumpulan dan pengolahan data untuk mengembangkan teori. Kajian demikian dapat dilakukan dengan mengembangkan teori dan dapat pula dilakukan dengan mengembangkan teknik penelitian partisipatif yang menuntut keterlibatan peneliti secara intensif. Penelitian ini merupakan studi kasus, karena itu data dikumpulkan dan diolah untuk mengembangkan model deskriptif yang merangkum semua gejala kasus.
Untuk menarik kesimpulan, data yang dihimpun diolah melalui proses reduksi, sajian data dan verifikasi. Analisis data seperti ini menerapkan model interaktif dari Miles dan Huberman (1992). Proses reduksi data merupakan proses penghalusan atau penyederhanaandengancara pengkodean, pengklasifikasian dan pembuangan bagian-bagian tertentu yang dianggap tidak relevan dengan fokus penelitian. Penyajian data dilakukan dalam wujud sekumpulan data atau informasi yang telah tersusun rapi sehingga dapat lebih mudah ditangkap maknanya dan dapat disajikan dalam bentuk yang lebih mudah dipahami. Verifikasi adalah upaya untuk menghubungkan data dengan berbagai gejala lainnya. Verifikasi data dalam penelitian kualitatif ini dilakukan secara terus menerus sepanjang proses penelitian berlangsung. Sejak awal memasuki lapangan dan selama proses pengumpulan data, peneliti berusaha menganalisis dan mencari makna dari data yang dikumpulkan dengan mencari pola, hubungan persamaan, kemudian diambil kesimpulan yang masih bersifat tentatif. Dengan semakin bertambahnya data dengan melalui proses verifikasi secara terus-menerus, diperoleh kesimpulan yang bersifat 'grounded'. Dengan kata lain, setiap kesimpulan senantiasa dilakukan verifikasi selama penelitian berlangsung.

Teori interaksi simbolik diperkenalkan oleh George Herbert Mead (1863-1931). Teori ini merupakan aliran sosiologi Amerika yang lahir dari tradisi psikologi. Karya-karya psikologi Amerika seperti William James, James Mark Baldwin dan John Dewey telah mempengaruhi sosiolog Charles $\mathrm{H}$. Cooley, yang kemudian membantu 
pengembangan teori psikologi sosial Amerika. Kemudian pada tahun 1950-an teori interaksi simbolik dikembangkan lagi oleh salah seorang murid Mead, yaitu Herbert Blumer, sampai dengan tahun 1960-an.

Psikologi-sosial Mead didominir oleh pandangan yang melihat realitas sosial sebagai proses ketimbang sebagai sesuatu yang statis. Manusia maupun aturan sosial berada dalam proses 'akan jadi' bukan sebagai fakta sudah lengkap (Poloma, 2007: 256). Menurut Mead, interaksi-simbolis dilakukan menggunakan bahasa sebagai satu-satunya simbol yang terpenting dan melalui isyarat. Simbol bukan merupakan fakta-fakta yang sudah jadi, simbol berada dalam proses yang kontinyu. Proses penyampaian makna inilah yang merupakan 'subject matter' dari sejumlah analisis kaum interaksisimbolis. Dalam interaksi orang belajar memahami simbol-simbol konvensional, sehingga mampu memahami peranan aktor-aktor lainnya (Poloma, 2007 : 258). Mead tertarik mengkaji interaksi sosial, dua atau lebih individu berpotensi mengeluarkan simbol yang bermakna. Perilaku seseorang dipengaruhi oleh simbol yang dikeluarkan orang lain, demikian pula perilaku orang lain tersebut. Melalui pemberian isyarat berupa simbol, kita mengutarakan perasaan, pikiran, maksud, dan sebaliknya dengan cara membaca simbol yang ditampilkan orang lain, kita menangkap pikiran, perasaan orang lain tersebut.

Cara manusia mengartikan dunia dan dirinya berkaitan erat dengan masyarakatnya. Mead (Efiendy, 2000: 391-2) melihat pikiran (mind) dan dirinya (self) menjadi bagian dari perilaku manusia, yaitu bagian interaksinya dengan orang lain. Interaksi itu membuat dia mengenal dunia dan dirinya sendiri. Mead menambahkan bahwa pikiran (mind) dan aku/diri (self) berasal dari masyarakat (society) atau proses-proses interaksi. Jadi tidak ada pikiran yang lepas bebas dari situasi sosial. Berpikir adalah hasil internalisasi proses interaksi dengan orang lain. Berlainan dengan reaksi binatang yang bersifat naluriah dan langsung, perilaku manusia diawali oleh proses pengertian dan penafsiran. Menurut teori interaksionisme simbolik, pikiran mensyaratkanadanyamasyarakat; dengan kata lain, masyarakat harus ada lebih dulu ada, sebelum adanya pikiran (Mulyana, 2001: 84). Dengan demikian, pikiran adalah bagian integral dari proses sosial, bukan malah sebaliknya: proses sosial adalah produk pikiran (Ritzer \& Goodman, 2004: 290).

Pandangan Mead menitikberatkan ilmu psikologi dan sosial, tentang gambaran manusia sebagai pelaku, sebagai makhluk yang memiliki 'diri sendiri'. Pandangan mengenai 'diri sendiri' mengandaikan manusia sebuah mekanisme interaksi dengan dirinya sendiri untuk menghadapi dunia luar. Mekanisme tersebut digunakan dalam membentuk dan menuntun tindakannya. Dengan mekanisme interaksi diri sendiri tersebut, manusia berhenti menjadi makhluk yang hanya sekadar beraksi akibat faktor luar, faktor dalam atau keduanya, tetapi ia bertindak pada dunianya, menginterpretasikannya.

Interaksionisme simbolik, merujuk pada karakrer interaksi khusus yang terjadi antarmanusia. Sifat khusus ini terdapat pada kenyataan bahwa manusia menginterpretasikan dan mendefinisikan antara tindakan yang satu dengan yang lainnya. Inti dari pemikiran Mead adalah 
bahwa manusia memiliki dirinya sendiri, dia juga dapat menjadi objek bagi dirinya sendiri, sehingga dia bisa melakukan tindakan sesuai dengan keinginannya sendiri (Soeprapto, 2002: 167). Mead berpendapat bahwa dalam pembentukan tindakan tersebut selalu terjadi kontak sosial, di mana hal ini sangat vital dalam pemahaman interaksionisme simbolik pada dasarnya tindakan kelompok sedikitnya serupa dengan tindakan individu. Masing-masing individu memadukan tindakan mereka dengan tindakan yang lain untuk memastikan tindakan apa yang akan dia ambil. Mead menyebut ini sebagai 'mendapat peran'. Dalam proses mendapatkan peran ini, masing-masing individu harus bisa memastikan tujuan tindakan individu yang lain. Dia bertindak atas dasar interpretasi dari tindakan orang lain. Begitulah cara yang mendasar bagaimana suatu tindakan kelompok terjadi dalam masyarakat.

Pandangan Mead tentang diri terletak pada konsep "pengambilan peran orang lain" (taking the role of the other\}. Konsep Mead ini merupakan penjabaran "diri sosial" (social self) dari Colley. Sehubungan dengan prosesproses tersebut yang mengawali perilaku manusia, maka pengambilan peran (role taking) amat penting. Sebelum seseorang bertindak, ia membayangkan dirinya dalam posisi orang lain dan mencoba untuk memahami apa yang diharapkan orang itu. Semakin mampu seseorang mengambil peran-peran sosial tersebut, semakin terbentuk identitas atau kediriannya. Bagi Mead dan pengikutnya, individu bersifat aktif, inovatif yang tidak saja tercipta secara sosial, namun juga menciptakan masyarakat baru yaug perilakunya tidak dapat diramalkan.
Dalam pandangan interaksi simbolik, sebagaimana ditegaskan Blumer, proses sosial dalam kehidupan kelompoklah yang menciptakan dan menegakkan aturan-aturan, bukan aturanaturan yangmenciptakan danmenegakkan kehidupan kelompok. Dalam konteks ini, makna dikonstruksikan dalam proses interaksi, dan proses tersebut bukanlah suatu medium yang netral yang memungkinkan kekuatan-kekuatan sosial memainkan perannya, melainkan justru merupakan substansi sebenarnya dari organisasi sosial dan kekuatan sosial.

Interaksionisme simbolik mengakui bahwa interaksi adalah suatu proses interpretatif dua arah. Salah satu fokus interaksi simbolik efek dari interpretasi terhadap orang yang tindakannya sedang diintrerpretasikan. Salah satu kontribusi teori ini, seperti dikemukakan Jones (Mulyana, 2002: 106) adalah menjabarkan berbagai macam pengaruh yang ditimbulkan penafsiran orang lain terhadap identitas atau citra diri individu yang merupakan objek interpretasi ini.

Berkaitan dengan ini, Goffman menyebut "ketertiban interaksi" (interaction order): struktur, proses, dan produk interaksi sosial. Ketertiban interaksi muncul untuk memenuhi kebutuhan akan pemeliharaan "keutuhandiri". Goffman dalam hal ini memusatkan perhatiannya pada dramaturgi atau pandangan atas kehidupan sosial sebagai serangkaian pertunjukan drama yang mirip dengan pertunjukan drama di panggung (Ritzer \& Goodman. 2004: 296-7).

Metode yang dipergunakan dalam penelitian ini adalah metode deskriptif dengan pendekatan kualitatif. Penggunaan metode deskriptif agar dapat 
menggambarkan sifat-sifat individu, kelompok, dan keadaan atau situasi kehidupan sosial budaya. Hal ini sesuai dengan pendapat Selitz (Tan, 1984:42), bahwa penelitian deskriptif mencoba menggambarkan tentang sifatsifat individu, keadaan, gejala-gejala dalam kelompok tertentu, menentukan adanya hubungan tertentu antara satu gejala dengan gejala lainnya dalam masyarakat.

Adapun pendekatan kualitatif berguna untuk menggambarkan suatu realita dan kondisi sosial dalam masyarakat. Menurut Garna (2007 : 4445), pendekatan kualitatif dicirikan oleh tujuan penelitian yang berupaya guna memahamigejala-gejala yang sedemikian rupa tak memerlukan kuantifikasi, atau karena gejala-gejala tersebut tak memungkinkan diukur secara tepat. Pendekatan kualitatif termasuk dalam naturalistic inquiry, manusia sebagai instrumen karena penelitiannya yang sarat oleh muatan naturalistik, artinya peneliti yang terlebih dahulu perlu sepenuhnya memahami dan bersifat adaptif terhadap situasi sosial yang dihadapi dalam kegiatan penelitiannya itu. Uraian tentang penelitian melalui pendekatan kualitatif, Moleong dengan mengacu kepada pendapat Bogdan dan Tylor (1975), Guba dan Tylor (1985), serta Kirk dan Miler (1986) mengemukakan bahwa pendekatan kualitatif memiliki ciri-ciri, pertama, bersumber kepada pengamatan kualitatif yang dipertentangkan dengan pengamatan kuantitatif; kedua, kualitas menunjuk kepada segi alamiah yang dipertentangkan dengan kuantum atau jumlah; ketiga, penelitian kualitatif diartikan sebagai penelitian yang tidak mengadakan penghitungan.(Garna, 2007: 46).

\section{B. Uga Bandung: Ramalan dan Antisipasi Terhadap Fenomena Perubahan Alam}

Kota Bandung adalah kota yang berada di wilayah Jawa Barat dan merupakan ibu kota Provinsi Jawa Barat, terletak pada $107^{\circ}$ Bujur Timur dan $6^{\circ} 55^{\prime}$ Lintang Selatan. Kota Bandung sangat strategis dilihat dari berbagai aspek, seperti komunikasi, perekonomian maupun keamanan, karena Kota Bandung terletak pada pertemuan poros antara jalan raya barat-timur yang memudahkan hubungan dengan Jakarta sebagai ibu kota negara. Dilihat dari topografisnya Kota Bandung terletak pada ketinggian 768 meter dpl., titik tertinggi di daerah utara dengan ketinggian 1.050 meter dan terendah di sebelah selatan dengan ketinggian 675 meter dpl. Wilayah Kota Bandung dari bagian selatan hingga batas jalan kereta api kontur tanahnya relatif datar, sedangkan dari batas jalan kereta api ke bagian utara kontur tanahnya relatif menanjak dan berbukit, sehingga memberikan kesan panorama yang indah.

Pembangunan Kota Bandung sepenuhnya dilakukan oleh rakyat Bandung di bawah pimpinan Bupati R.A. Wiranatakusumah II. "Dalam pembangunan kota itu, rupanya penduduk Kampung Balubur Hilir merupakan tenaga inti yang sangat berperan aktif' (Hardjasaputra, tanpa tahun). "Dengan demikian, tidaklah berlebihan bila dikatakan bahwa Bupati R.A. Wiranatakusumah II (1794 1829) adalah pendiri Kota Bandung. Kota Bandung mengalami perubahan yang penting, dengan adanya perubahan besar-besaran yaitu rumah-rumah yang beratap ilalang diganti dengan genting" (Hardjasaputra, 1999) . 
Ada sebuah kejadian yang dicatat sejarah, ketika Daendells seusai meresmikan jembatan, ia didampingi Bupati Bandung berjalan terus dari arah barat ke arah timur sampai pada suatu tempat -- depan Kantor PU Provinsi sekarang-- di tempat itu, ia menancapkan tongkatnya sambil berkata: "Zorg, dat als ik terug kom hier een stad is gebeound!" 'Coba usahakan, bila saya datang kembali, di tempat ini telah dibangun sebuah kota!' (Victor Ido, "Indie in den Goeden Ouden Tijd, Nirom, 1935; Kunto, 1984 : 14). Selanjutnya di tempat Daendells menancapkan tongkatnya itu, dibuatlah patok untuk dijadikan tugu peringatan yang menyatakan tanda Kilometer "O" (Nol) untuk Kota Bandung. Dalam hal ini jelas bahwa Daendells sangat berperan dalam pembangunan Kota Bandung, wilayah yang asalnya hanya sebuah Bergdessa 'desa udik yang sunyi sepi' menjadi sebuah kota yang besar. Bupati Bandung pada masa itu pun terus membangun Bandung hingga terwujud sebuah kota yang indah penuh sanjung.

Atas dorongan dan usulan Dr. Ir. R. van Hoevell, pemerintah Kolonial Belandamempertimbangkan perpindahan ibu kota Priangan dari Cianjur ke Bandung, yang di kemudian hari kota ini mendapat julukan Parijs van Java atau Europa in de Tropen 'Eropa di daerah Tropis' (Kunto, 1996: 9). Gubernur Jenderal Charles Ferdinand Pahud memerintahkan pemindahan ibu kota Keresidenan Priangan dari Cianjur ke Kota Bandung sesuai dengan permintaan Adries de Wilde. Bandung menjadi ibu kota Priangan, dari sinilah diperkirakan munculnya Uga Bandung, "Bandung heurin ku tangtung". Adapun uga-uga lainnya yang mendukung perkembangan Kota Bandung muncul setelahnya.
Untuk menentukan siapa yang menciptakan uga dan kapan uga itu menyebar di masyarakat Jawa Barat umumnya maupun masyarakat Bandung khususnya, secara umum sangat sulit untuk diketahui. Nara sumber atau penutur yang ditemui penulis, hanya menuturkan bahwa: "Ieu uga téh ti aki, nya mungkin aki gé ti bapana aki deui, nu ditarima sacara lisan bari ngadongéng" 'Uga ini berasal dari kakek, mungkin kakek juga dari bapaknya kakek yang diwariskan secara lisan sambil mendongeng'. (Wawancara: Abah Wiranta, 80 Th., dari Kampung Tugu, Lembang). Atau bagi masyarakat yang ada di perkotaan, mereka mendapatkan uga hasil dari membaca referensi yang telah diterbitkan seperti dalam cerita pantun atau buku lainnya.

Menurut Ki Arjo yang dikutip Adimihardja (1983: 46), uga dapat diterima dengan cara meditasiatau dengan masuk ke dunia roh karuhun melalui sesajen, berpuasa dan mengadakan upacara ritual. Melihat prosesnya, uga dapat terlahir dari sebuah ilham, insting, meditasi dan hasil kontemplasi 'dejavu' dari orang yang menjadi arbitator dengan pencipta-Nya. Kemudian dengan kecermatan intelegensinya atau akal budi yang di dalamnya meliputi pikiran, perasaan, dan khayalan, karuhun mampu mengabstraksi dan menggeneralisasikan jalannya kehidupan di masa yang akan datang. Karuhun yang menerima uga

$1 \quad$ Uga yang dimaksud di sini adalah semacam perintah atau bisikan dari karuhun untuk melakukan perpindahan dari kampung asal ke kampung baru, yang kemudian akan menemukan tempat yang disebut Lebak cawéné atau kehidupan baru 'a new life movement' (lihat juga, Warnaen.1987:11) 
seperti itu adalah orang pilihan. Ia bukan sembarang orang, karena pengalaman yang dialaminya merupakan keterpaduan antara dirinya dengan alam dan bagian dari hukum alam yang berlaku tanpa tendensi.

Kalimat atau ucapan yang dipergunakan dalam uga, bukan sematamata ucapan yang tidak bermakna, melainkan sebuah bimbingan agar manusia yang menerimanya tidak salah dalam melangkah di kemudian hari. Biasanya uga merupakan ungkapan dan ramalan yang mengungkapkan tandatanda zaman yang akan berubah. Ramalan tentang perubahan alam di dalam uga bukan sebuah ramalan hampa yang hanya memberi berita kesenangan atau berita yang menakutkan, melainkan uga dapat memberi isyarat agar generasi selanjutnya menjadi manusia yang waspada, tanggap dan cakap dalam menghadapi fenomena perubahan alam. Atau dengan kata lain bahwa dengan adanya uga ini manusia Sunda mampu mengantisipasi perubahan fenomena alam, sehingga hal-hal yang dianggap buruk tidak terjadi.

Uga yang tersebar di masyarakat, salah satunya adalah uga Siliwangi atau wangsit Siliwangi. Uga hanya diwariskan secara lisan dari memori kolektif masyarakatnya, maka akibatnya bahasa yang dipergunakan pun akan selalu berubah (dinamis) sesuai dengan waktu dan orang yang menuturkannya, demikian seterusnya. Sehingga dewasa ini, uga yang tersebar di masyarakat umumnya sudah tidak lagi mempergunakan katakata yang arkais 'heubeul' seperti katakata yang dipergunakan dalam naskah Siksa Kanda Ng Karesian, Amanat Galunggung, atau naskah-naskah Sunda kuno lainnya. Karena bahasa bersifat arbitrer, maka kalimat yang dipergunakan dalam uga Siliwangi sudah tidak sesuai dengan kalimat Prabu Siliwangi yang diucapkannya dahulu melainkan dengan bahasa sekarang, namun makna yang terkandung di dalamnya masih tetap tersampaikan sesuai dengan asalnya. Begitu pula dengan bahasa yang dipergunakan dalam Uga Bandung, kebanyakan bahasa yang dipergunakan adalah bahasa Sunda kiwari 'sekarang'.

\section{Bandung heurin ku tangtung ${ }^{2}$}

(Bandung sesak oleh 'tangtung')

Morfem dasar terikat tangtung, secara harfiah berarti 'diri', namun secara konstekstual, dapat diinterpretasikan dari berbagai sudut pandang. Untuk mengerti kata-kata tertentu folk-etymology, seperti morfem dasar terikat tangtung di atas, dengan mempergunakan istilah yang diberikan Warnaen (1987) harus dijadikan sebagai kata kunci key word agar secara kontekstual dapat dipahami makna yang utuh yang terkandung di dalamnya. Selain itu, masyarakat Sunda sudah mengenal apa yang disebut pancacuriga yaitu silib-sindir, simbul, siloka dan sasmita, yang berguna mengkaji secara hermeneutika atau semiotika. Biasanya dalam mengkaji kandungan nilai yang terdapat dalam dunia folklor Sunda, harus disertai dengan kualitas berpikir dan berasa yang lantip jeung surti nu wawuh ka semuna, apal ka basana 'mampu membaca dan memaknai yang tersurat dan tersirat'. Dengan pancacuriga ini kita berkemungkinan dapat membaca simbol-simbol yang diberikan dan mampu memasuki gerbang alam pikiran karuhun yang dicetuskannya.

2 Sumber: Asep Dhani (33 Th), 15 April 2008, tempat : Panyileukan - Cibiru. 
Untuk memahami morfem dasar terikat tangtung ini, kita mencoba mempergunakan realitas yaitu sesuatu yang dipercayai 'ada', maka 'ada' pun tidak harus nyata, karena ada yang disebut realitas esensi dan ada realitas material atau realitas faktual. Realitas esensi itu abstrak dan lebih merujuk pada maknawi, sedangkan realitas material atau faktual itu nyata yang menempel pada ruang dan waktu atau yang disebut dengan eksistensi. Realitas material lebih bersifat publik dan objektif. Memahami morfem dasar terikat tangtung di atas, yang secara harfiah atau realitas material atau faktual berarti 'diri', namun makna secara kontekstual atau secara realitas esensi $k u$ tangtung (dengan penambahan preposisi $k u^{\prime}$ 'oleh')dapatdiinterpretasikan bermacam ragam pengertian. Melihat realitas material atau faktual dan realitas esensi, morfem dasar terikat tangtung dapat diinterpretasikan :

a. secara harfiah, menunjuk pada arti diri, manusia, penduduk;

b. secara fisik, menunjukkan gedung, perumahan, sarana dan prasarana;

c. secara maknawi dapat diartikan sebagai pendapat, pendirian, ideologi, kehendak, budaya, dan sebagainya.

Latar belakang sejarah lahirnya Uga Bandung, diperkirakan ketika Bandung dijadikan ibukota Karesidenan Priangan yang dipindahkan dari Cianjur. Karuhun melihat kejadian ini akan berdampak pada perkembangan Kota Bandung, maka lahirlah Uga Bandung yang berbunyi "Bandung heurin ku tangtung".

Bandung heurin ku tangtung, memiliki konsep makna yang negatif, hal itu muncul oleh adanya kata heurin yang berkonotasi makna negatif. Untuk menetralisir pemaknaan negatif ini, maka perlu adanya konsep yang menimbulkan konsep positif, misalnya dalam hal pembangunan yang berkelanjutan dengan berdasarkan kearifan lokal agar konsep heurin tidak menjadi sebuah kenyataan. Bandung terasa lapang dengan konsep pembangunan yang berwawasan lingkungan.

Uga Bandung di bawah ini lebih mengabstraksikan keadaan Kota Bandung yang heurin ku tangtung, yang disebabkan oleh tangtung yaitu :

\section{Bandung heurin ku tangtung,} gegek pangeusi nagrina, rajeg pamadeganana, paluhur-luhur tangtungan, pagirang-girang kahayang, laju pangeusi Bandung, pada bingung pada linglung, teu karasa Bandung geus jadi talaga deui. ${ }^{3}$

Morfem dasar terikat tangtung diabstraksikan dengan gegek pangeusi nagrina, rajeg pamadeganana, paluhurluhur tangtungan, pagirang-girang kahayang 'sesak penduduknya, beragam pendiriannya, bermacam ragam ide, berlawanan keinginan'. Kesemrawutan dan ketidakteraturan di berbagai masalah Kota Bandung, menyebabkan penduduknya merasa bingung dan tak tahu arah tujuan, sehingga tidak terasa Bandung kemudian menjadi lautan kembali. Lautan dapat diinterpretasikan secara realitas material atau faktual dan realitas esensi yaitu menjadi danau kembali seperti danau purba kembali atau Bandung penuh sesak oleh manusia yang

3 Sumber: Ua Bandung (65 Th), 13 Oktober 2007, tempat : Pangampaan Bandung 
diibaratkan menjadi lautan manusia, lautan ide, lautan pendirian, dan lain sebagainya.

Akankah Bandung di kemudian hari kembali lagi menjadi sebuah danau? Kemungkinan bisa saja terjadi, hal itu diakibatkan oleh banyaknya faktor yang mendukung bencana itu muncul, misalnya lahan hijau untuk resapan air saat ini berubah fungsi menjadi lahan perumahan. Kawasan Bandung Utara yang sejak dahulu selalu dijadikan kawasan konservasi, dewasa ini kawasan itu menjadi kawasan perumahan elite yang tidak menyisakan kawasan untuk resapan air dan menahan terjadinya banjir. Mungkin inilah yang menyebabkan Bandung jadi talaga deui. Perbuatan manusia yang sudah melupakan nilai-nilai kearifan dan sudah tidak lagi mementingkan keseimbangan alam, menyebabkan Bandung selalu dilanda banjir dan banjir. Menurut Otto Soemarwoto (2002) koefisien air larian di Kota Bandung pada tahun 1960-an kira-kira 40\% dan Bandung Utara 25\%. Sekarang di daerah kota diperkirakan $75 \%$ dan di kawasan Bandung Utara $60 \%{ }^{4}$. Tingginya air larian menyebabkan menurunnya air yang meresap ke dalam tanah, sehingga di musim kemarau mengalami kekeringan. Sebaliknya tingginya air larian tersebut menimbulkan banjir di musim hujan.

Perkembangan Kota Bandung dari hari ke hari yang semakin tidak terkendali. Kalimat gegek pangeusi nagrina dapat dilihat dari peta wilayah Kota Bandung, menunjukkan bahwa tiga wilayah di Kota Bandung diduga menjadi

4 Pikiran Rakyat. Bandung Raya "Terpadat di Dunia” Senin, Tgl. 30 Maret 2009. kota terpadat di dunia, karena kepadatan penduduknya di atas 13.000 jiwa per kilometer perseginya. Tiga wilayah itu adalah Cicadas, Kiaracondong, dan Bandung Kulon. Rumah-rumah semakin terlihat berhimpitan dan bahkan banyak rumah yang diisi oleh tiga kepala keluarga. Padahal idealnya kepadatan penduduk itu lima ratus jiwa per kilometer persegi. Perkembangan dan pembangunan yang menjadikan Bandung menjadi gegek pangeusi nagrina yang diakibatkan oleh kebijakan pemerintah sendiri yaitu menjadikan Kota Bandung sebagai kota singgah. Dengan banyaknya bermunculan factory outlet di mana-mana di sepanjang jalan yang salah peruntukan. Hal ini mengakibatkan banyaknya pendatang wisatawan Nusantara yang datang dari berbagai kota.

3. Jaga Bandung bakal kakeueum, sabeulah urang Bandung ka kidul bagéanana ka Gunung Cikuray, sabeulahna ka kalér, bagéanana ka Gunung Tangkubanparahu. ${ }^{5}$

\section{Urang Bandung mah bakal ka tegal} haréndong di daérah pakidulan Pangaléngan, di dinya aya nu disebut Tegal Bandung, cawisan keur urang Bandung. ${ }^{6}$

Uga/3/menunjukkan adanya sebab akibat, berbeda dengan uga /4/ yang hanya menyebutkan penduduk Bandung akan mengungsi tanpa sebab. Dalam uga /3/ sebab akibat yang disebutkan itu

5 Sumber: Abah Wiranta, (80 Th), 13 Juni 2008, tempat: Tugu Lembang

6 Sumber: Ahmad Safii Hidayat (59 Th) \& Hariri (28 Th), 12 Maret 2008, tempat: Cigondewah. 
ditimbulkan ketika Bandung mengalami perubahan dengan cara terendam air atau menjadi lautan. Penduduk Bandung akan mengungsi atau pindah ke tempat yang telah ditentukan, yaitu Tegal Haréndong, Gunung Cikuray, dan Tegal Bandung untuk penduduk Bandung Selatan sedangkan Gunung Tangkubanparahu diperuntukkan bagi penduduk Bandung Utara. Tegal Haréndong adalah suatu tempat yang letaknya sangat samar, artinya hanya ada dalam realitas esensi. Itu pun hanya disebutkan oleh informan, bahwa daerah itu berada di sebuah hutan panyampayan di daerah Citambur.

Melihat rentang waktu penciptaan hingga penutur kedua dan seterusnya, uga /3/ dan /4/ di atas dapat menunjukkan kala atau waktu yang diprediksi akan terjadi di waktu yang akan datang dan sifatnya peringatan, kelak bagi masyarakat Bandung telah mempunyai peruntukkan tanah untuk 'mengungsi' ketika Bandung terjadi 'bencana'. Orientasi lokus dan berlakunya uga ini adalah lokal Kota Bandung dan pada akhirnya menuju ke arah luar Kota Bandung, yaitu daerah yang merupakan tanah cawisan (tanah peruntukan). Adapun akibat dari hasil yang diprediksi adalah perubahan fisik, yaitu 'tenggelamnya' Kota Bandung yang berakibat pindahnya penduduk untuk menempati daerah cawisan yang telah ditentukan. Begitu pula dengan pembuktian dari prediksi uga ini menyatakan belum terjadi, hal tersebut dapat dilihat dari gambaran kala yang dinyatakan dengan kata jaga, dan bakal yang artinya menunjuk pada waktu yang akan datang.

\section{Faktor-faktor Penyebab Bandung Heurin Ku Tangtung}

Kota Bandung, pada pertengahan abad ke-19 masih merupakan 'desa' yang sunyi sepi dikenal dengan sebutan een kleine berg dessa 'desa pegunungan yang mungil'. Bandung 'desa' yang terdiri atas 25 sampai 30 rumah merupakan suatu daerah hutan buas, waktu itu tatar Bandung tidak lebih dari sebuah hutan rimba, apabila memasuki daerah ini sering terucap top badak top maung kata orang Sunda.

Menurut Prof.Dr.EC. Godee Moisbergen, Kepala Arsip Negara di Batavia (1935) tercatat pada tanggal 24 April 1820, Residen Priangan yang berkedudukan di Cianjur telah mengadakan inspeksi ke kota mungil Bandung. Residen telah berembug dengan Regent 'Bupati' dan Panghulu Bandung untuk membangun sekolah di kota ini. Dengan munculnya sekolah tersebut maka Bandung mendapat julukan Kota Pendidikan. Kemudian, seorang seniman mencipta nyanyian yang berbunyi "Nelengnengkung nelengnengkung, geura gede geura jangkung, geura sakola ka Bandung geura makayakeun indung" yang menjadi impian setiap orang tua untuk menyekolahkan anaknya di Kota Bandung.

Kemudian pada tahun 1866 , di kota ini dibangun sebuah sekolah Kweekschool 'Sekolah Guru' yang oleh orang-orang pribumi disebut sebagai Sakola Raja. Disebut Sakola Raja, karena banyak anak-anak 'raja' (kepala suku, kepala nagari) dari luar Pulau Jawa yang bersekolah di sekolah ini (Kunto 1996 :19). Bandung sebagai kota pendidikan, terekam dengan baik dalam sebuah buku bacaan untuk anak-anak sekolah dasar yang dikarang oleh AC Deenik dan 
Rd. Djajadiredja dalam bukunya yang berjudul Rusdi Djeung Misnem (1922)

Kemudian di Bandung pula, terdapat sekolah HBS 'Hogere Burgerschool' setingkat SMA di J1. Belitung, salah satu alumninya adalah Sri Sultan Hamengkubuwono IX. Ir. Soekarno, merupakan salah seorang alumni dari Technische Hooger School ' $\mathrm{TH}$ ' yaitu perguruan tinggi teknik pertama di Indonesia yang diresmikan pada tahun 1920. Sekolah ini di kemudian hari dikenal dengan sebutan Institut Teknologi Bandung 'ITB'. Untuk kepentingan sandang, Departemen Perekonomian Hindia Belanda, pada tahun 1934 mendirikan sekolah Textiel Inrichting Bandoeng 'TIB' yang kini dikenal dengan Institut Teknologi Tekstil 'ITT' . Pendidikan bagi kaum remaja putri tak lepas dari perhatian seorang pahlawan nasional, yaitu Ibu Rd. Dewi Sartika, pada tahun 1925 mendirikan sebuah sekolah yang dinamakan 'Sakola Istri' di Jalan Kautamaan Istri. Sekolah ini untuk mendidik kaum remaja putri Sunda dalam mencapai cita-citanya tidak saja sebagai wanita yang mengurus rumah tangga, melainkan dituntut untuk menjadi wanita yang mandiri.

Pemerintah Kolonial Belanda pada tahun 1920 berencana memindahkan ibu kota Hindia Belanda dari Batavia ke Kota Bandung, maka pada tahun 1921, di daerah Dago dibangun pembangkit tenaga listrik, sehingga Kota Bandung di waktu malam hari rapang damar teu diminyakan, bermandikan cahaya lampu sampai ke pelosok-pelosok kota.

Bandung yang kini menjadi sebuah kota metropolitan, sudah sangat sesak dengan pembangunan yang dilakukan oleh masyarakatnya. Pembangunan sarana dan prasarana diperlukan untuk memenuhi kebutuhan dasar hidupnya.

\section{Fungsi Uga Bandung}

\section{Uga Bandung Berfungsi Memprediksi}

Uga bukan saja merupakan sebuah ramalan, tetapi dia merupakan suatu bentuk memori sebuah komunitas yang di dalamnya terkandung a) harapan, yang diidamkan; b) pesan moral, yang mampu mengantisipasi berbagai keadaan yang sedang dijalani oleh komunitas itu; c) sebagai petunjuk ke arah perubahan yang berlaku dari zaman ke zaman.

Uga sebagai prediksi yang diwasiatkan olehkaruhun kepada generasi penerus, dapat memberikan dua pilihan kepada kita, yaitu a) menerima prediksi atau ramalan sebagai sesuatu yang tak dapat dihindari dan mati, b) mengubah peringatan itu menjadi kesempatan untuk mencegah masa depan yang 'mengerikan' sesuai dengan ramalannya. Dalam Uga Bandung, biasanya prediksi diberikan dalam bentuk perlambang atau simbol-simbol yang sesuai dengan latar belakang budaya manusia Sunda.

Uga Bandung, merupakan gambaran perkembangan fisik dan kehidupan sosial budaya masyarakat Kota Bandung. Bandung heurin ku tangtung adalah sebuah gambaran yang memiliki orientasi material atau faktual dan orientasi esensi. Kedua makna yang dihasilkan oleh orientasi material atau faktual dan orientasi esensi menunjukkan pada perkembangan manusia dan fisik atau sarana dan prasarana di Kota Bandung. Hal tersebut disebabkan oleh berbagai faktor penyebabnya, seperti Bandung sebagai kota wisata dan belanja dengan banyaknya factory outlet, salah satu penyebabnya, yang terus tumbuh dan bekembang. Sesuai dengan pernyataan Uga Bandung yang menyatakan bahwa Bandung heurin ku tangtung, maka 
dalam perkembangan pembangunan fisik Kota Bandung dan Bandung sebagai ibu kota provinsi sangat menunjang terhadap pembuktian uga tersebut.

\section{Uga B andung Berfungsi Mengantisipasi}

Dengan uga kita dapat melakukan antisipasi bagi perkembangan zaman, sehingga ketika kita berbuat, kita sudah dibekali dengan 'obor' dan pegangan. Oleh karena uga dapat memberikan suatu pandangan dan arah perubahan yang bakal terjadi di masa depan, hanya kita perlu mengantisipasinya. Dengan mempelajari peristiwa kemarin, kita dapat menghadapi masa depan secara lebih baik - jadi memiliki kekuatan untuk mengubah masa depan sebelum terjadi.

Dalam melakukan antisipasi, mungkin kita selalu was-was hal tersebut mungkin disebabkan visi kita sendiri yang mengalami distorsi, tidak tepat, dan tidak lengkap atau ramalan itu masih belum terpenuhi. Kesulitan itu muncul dalam memutuskan apakah $u g a$ itu merupakan suatu prediksi yang salah, atau apakah merupakan ramalan masa depan yang masih belum terpenuhi, ada beberapa contoh $u g a$ yang mungkin uga itu akan terungkap di kemudian hari, tahun depan, atau bahkan tidak lama lagi. Antisipasi memungkinkan kita untuk menyadari bahwa ramalan itu adalah peringatan bagi kita untuk mengindahkannya dan mengambil tindakan terhadap situasi, masa depan kita sebelum terlambat.

Uga Bandung, dapat mengabarkan ramalan suatu perubahan di masa yang akan datang. Biasanya perubahan itu dapat bersifat perubahan sosial dan perubahan fisik dari suatu masyarakat. Perubahan sosial terjadi karena perubahan pada sikap, moralitas, atau etika yang terjadi pada masyarakat Kota Bandung. Adapun perubahan fisik terjadi pada perkembangan dalam bidang pembangunan sarana dan prasarana yang ada di kota itu sendiri. Kedua perubahan itu sudah digambarkan dan diramalkan sesuai dengan perkembangan zaman yang akan dilaluinya. Maka apabila dalam masyarakat terjadi suatu fenomena yang baru, baik itu perubahan sosial dan perubahan fisik, dan mengganggu keseimbangan, masyarakat selalu kembali pada uga sebagai sebuah patokan. Kalimat geus aya dina ugana 'sudah ada dalam uga' menggambarkan bahwa fenomena itu mungkin perubahan yang sudah diatur sebelumnya, sehingga ramalannya sudah terbukti.

\section{SIMPULAN}

Uga Bandung merupakan tradisi lisan, sesungguhnya masih sangat relevan untuk diungkapkan pada masa kini, karena tradisi lisan memberikan pedoman bagaimana manusia menghayati hidupnya berkaitan dengan lingkungan dan alamnya. Dalam tradisi lisan khususnya Uga Bandung di dalamnya terkandung nilai, etika, moralitas, dan sebagainya.

Uga Bandung tersedimentasi dalam teks dan simbol yang tidak mudah untuk diterjemahkan. Dalam uga Bandunng membuka peluang pada langkah antisipatif atas suatu fenomena alam yang berakibat pada sebuah kejadian yang diprediksi $u g a$. Bila upaya mengantisipasi itu tidak dilakukan secara sungguh-sungguh, prediksi uga akan terjadi dan menjadi kenyataan.

Uga sebagai sebuah harapan harus difungsikan, sebab uga yang fungsinya memprediksi apabila tidak 
difungsionalisasikan tidak akan mempengaruhi manusia itu sendiri. Uga hanya sebatas kata-kata bijak karuhun apabila tidak dirasionalisasikan dan difungsikan ke dalam sikap dan tindakan nyata.

Nilai-nilai yang menjadi ciri identitas suatu budaya 'genus lokal' akan berkaitan erat dengan otentisitas perilaku /visi hidup masyarakat pendukung budaya lokal tersebut. Nilai-nilai kearifan lokal perlu disiasati secepatnya dan diaktualisasikan dalam kehidupan keseharian, agar nilai-nilai tadi tidak hanya sebatas knowledge atau kanyaho 'pengetahuan' saja

Harapan, pembuat kebijakan 'pemerintah' yang harus mampu mengungkap kearifan masyarakatnya dalam menghadapi fenomena alam ini, apalagi yang berhubungan dengan Kota Bandung.

\section{DAFTAR PUSTAKA}

Adimihadja, Kusnaka. 1983.

Generations From Banten : A wandering Spiritual Leader and His Followers In West Java. Thesis Submitted in Partial Fulfillment of The Requirements for the Degree of Master of Arts at The Australian National University.

Affandi, A.R. Moech. 1969.

Bandung Baheula. Bandung:

Guna Utama.
Casserer, Ernst. 1987.

An Essay on Man, Terjemahan Alois. A. Nugroho, Manusia dan Kebudayaan, Sebuah Esei Tentang Manusia Jakarta: Gramedia.

Geertz, Clifford. 1992.

The Interpretation of Cultures: Selected Essays. Dialihbahasakan oleh Francisco Budi Hardiman denganjudulTafsirKebudayan. Yogyakarta: Kanisius.

Hardjasaputra. Sobana. 1999.

Sejarah Kota Bandung 1810-

1906. Pemerintah Kotamadya Daerah Tingkat II. Bandung.

Hardjasaputra, Sobana.

Pembentukan Gemeente Bandung, MakalahTanpa Tahun.

Kunto, Haryoto. 1984.

Wajah Bandoeng Tempo Doeloe. B andung: PT. Granesia. 1986.

Semerbak Bunga di Bandung Raya. Bandung: PT. Granesia. 1996.

Balai Agung di Kota Bandung. Bandung: PT. Granesia.

Soeprapto, Riyadi. 2002.

Interaksionisme Simbolik: Perspektif Sosiologi Modern. Malang: Averroes Press. 
Warnaen, Suwarsih. dkk. 1987.

Pandangan Hidup Orang Sunda Seperti Tercermin dalam Tradisi Lisan dan Sastra Sunda.DepartemenPendidikan dan Kebudayaan. Direktorat Jenderal Kebudayaan. Bagian Proyek Penelitian dan Pengkajian Kebudayaan Sunda. Bandung. 